М. Попович // Науковий вісник Мукачівського державного університету. Серія: Педагогіка та психологія / голов. ред. : Т. Д. Щербан. - Мукачево, 2015. - Вип. 2. - С. 37-41.

\title{
References
}

1. Bila I. M. (2010), Konstruiuvannia yak zasib rozvytku tvorchosti doshkilniat [Designing as a means of developing the work of preschoolers], Doshkilne vykhovannia, No 5, pp. 10-13.

2. Bielienka H. V. (2006), Vykhovatel ditei doshkilnoho viku: stanovlennia fakhivtsia v umovakh navchannia: monohrafiia [Mentor of preschool children: becoming a specialist in a learning environment: a monograph], Svitych, Kiev, 304 p.

3. Artemova L. V. (2010), Priorytety v pidhotovtsi pedahohiv doshkilnoho profiliu [Priorities in preparing teachers of preschool education], Doshkilne vykhovannia. No 2, pp. 7-9.

4. Voitko L. O. (1997), Psykholohichna pidhotovka maibutnikh vykhovateliv [Psychological training of future educators], Rivne, pp.150-154.

5. Vorozhbit-Horbatiuk V. V. (2015), Komponenty hotovnosti maibutnikh vykhovateliv do orhanizatsii konstruktyvnoi diialnosti ditei doshkilnoho viku [Components of readiness of future educators for organization of constructive activity of children of preschool age], Mukachevo,. No 2. pp. 37-41.

УДК 378.37.011.3.016:81 243]=111

\section{PECULIARITIES OF THE FUTURE FOREIGN LANGUAGE TEACHERS' TRAINING BY MEANS OF PEDAGOGICAL TECHNOLOGIES (FOREIGN EXPERIENCE)}

Garapko Vitaliya, Birov Kristina

\section{ОСОБЛИВОСТІ НАВЧАННЯ МАЙБУТНІХ ВЧИТЕЛІВ ІНОЗЕМНИХ МОВ ЗАСОБАМИ ПЕДАГОГІЧНИХ ТЕХНОЛОГІЙ (ЗАРУБІЖНИЙ ДОСВІД)}

Гарапко B.I., Біров К.С.

Article is devoted to the role of modern pedagogical technologies in the future foreign language teacher training. A description of the importance and necessity of using pedagogical technologies in the training process has been given. Since their correct application greatly simplifies and improves the quality of the educational process has been described. Pedagogical technologies have been characterized by a wide range of classifications providing their various definitions.

Keywords: types of technologies, modern technologies, professional training of foreign language teachers, pedagogical technologies, future foreign language teachers.

Стаття присвячена ролі сучасних педагогічних технологій у підготовці майбутніх вчителів іноземної мови. Подано опис важливості та необхідності використання педагогічних технологій у навчальному прочесі. Оскільки їх правильне застосування значно спрощує та покращує якість навчального процесу, який є описано. Педагогічні технології характеризуються широким колом класифікацій, щуо забезпечує їх різні визначення.

Ключові слова: види технологій, сучасні технології, професіонал, навчання вчителів іноземної мови, педагогічні технологї, майбутні вчителі іноземних мов 
Over time, increasing scientific interest is being paid to the problem of preparing a foreign language teacher by means of pedagogical technologies, which became the subject of scientific research by foreign scientists. A number of scholarly works (I. Komensky, B. Likhachev, M. Clarin, I. Balitsky, N. Mukan, V. Volosovich, S. Bodnar, O. Slonovsky) are devoted to the notion of pedagogical technologies as well as special aspects of the training of future teachers of foreign language [2, p. 154].

The actual problem in foreign language teachers' training is the unity of theoretical and practical training, educational and research activities of students and teachers by means of modern educational technologies, which generally provides a tiered readiness of teachers to the profession. Mentors should keep on strengthening the students' behavioral, cognitive and emotional attitude components in balanced manner to let the students have all-rounded development [1].

The urgency of the issue of foreign experienceh has been emphasized not only by the necessity of theoretical consideration, but also by the practical application of promising achievements of developed foreign countries educational system and their transfer to the educational system of the training of future teachers in the field of foreign languages in Ukraine.

The purpose of the work is to determine the peculiarities of introducing pedagogical technologies into the practice of the future teacher of a foreign language based on foreign experience.

Since ancient times, pedagogy, as a science, continues to evolve and does not stand in one place. For many years, the necessary knowledge has been accumulated, pedagogical systems have been created, tested and until the best on the most necessary ones for humanity and for pedagogical science in particular have been developed. Based on the above scientific literature, the authors of this research concluded that the idea of "pedagogical technology" was characterized by typological division, similar to classification features. The present-day research papers dedicated to various educational aspects indicate the presence of different types of educational technologies [3].

There was a special need to upgrade and improve education. New and modern approaches to the organization of the educational process, methods and technologies of education and training appeared and spread.

The complexity and versatility of pedagogical activity is a factor that opens up space for many pedagogical technologies whose dynamics of production is constantly increasing. The wide spectrum, multivariate of pedagogical technologies necessitate their classification.

The most perfect among many is the classification of V. G. Seleukov, according to which pedagogical technologies are grouped according to various systemic and instrumental signs. V. Seleukov singled out six classification groups:

1) by the level of application;

2) on a philosophical basis;

3) on the leading factor in mental development;

4) from the scientific concept of learning experience;

5) in orientation to personal structures;

6) by the nature of the content and structure. [2, p.124].

Recently, the problem of future foreign language teachers training exacerbates the special attention in connection with the increased interest in the study of foreign languages, the strengthening of the priority of language education, which has been created in a modernized society in last few years [2].

The global need for the development of technological designs arose in connection with the idea of managing the pedagogical process. Implementation of it became possible on the basis of a systematic approach, which makes it possible to compare the various pedagogical skills that in their totality guarantee a positive educational result [4, p. 23].

Integration of the national education system into the European and world educational space has led to the necessity of finding and implementing the latest approaches to providing a 
qualitatively new level of professional training of pedagogical staff on the basis of preserving national treasures and using the best examples of world experience [5, p. 71].

Studying the experience of professional training of teachers in developed foreign countries opens new opportunities for improving the system of continuous pedagogical education in Ukraine in conditions of its adaptation to the requirements of the European educational space. Significant scientific interest is the progressive achievements of countries that demonstrate a high level of professional training of educators, in accordance with world standards; have rich historical traditions of education, which contributes to their leading role in science and education at the regional and global levels; have accumulated considerable experience in the field of professional training of teachers in new socio-cultural conditions [5].

According to modern notions, the teacher should act not so much as a source of knowledge and a controlling entity, as an organizer of independent active cognitive activity of students, their consultant, mentor, tutor and assistant. The base currently has such innovative educational technology training program used in the preparation of future teachers, as technology critical thinking, group learning technology, design technology, technology of individualization of the learning process and others.

It has been found that teachers working in a modern educational institution, not only need to know the range of available tools and their didactic purpose. But effectively use each of funds. As the only fully using not only basic but also aids training, person can achieve the goals of learning a foreign language. The XXI century - is the century of high technologies. Pedagogical technologies allow teachers to make language lessons more interesting and productive, increase students' motivation to learn a foreign language. Education and learning are strongly linked with society and its evolution and knowledge. In the field of formal education, pedagigical technologies have been increasingly deployed as tools to extend the learner's capacity to perceive, understand and communicate, as seen in the increase in different training programs and the use of the pedagogacal techniques as a learning support tool not only in the classroom. They can provide more flexible and effective ways for professional development for foreign teachers, improve teacher training, and connect teachers to the global teacher community too. This paper analyses a variety of strategies pedagogical technologies integration into foreign teacher's training. Based on the analysis of those strategies, it discusses new possibilities and challenges that technologies has brought to future foreign teacher training and professional development.

\section{Referrences}

1. Grechanik B.V. (2010), Innovatsiynyy potentsial vitchyznyanykh VNZ: osoblyvosti ta problemy yoho formuvannya [Innovation potential of domestic universities: the peculiarities of the problems of its formation], Investments: practice and experience, K., No. 11, p. 24.

2. Nisimchuk A. S. (2000), Suchasni pedahohichni tekhnolohiyi [Modern Pedagogical Technologies]: manual, K .: Prosvita, p. 368.

3. Sysoev S. O., Aleksyuk A.M., Volovik P. M., and others (2001), Pedahohichni tekhnolohiyi u neperervniy profesiyniy osviti [Pedagogical technologies in continuous vocational education]: monograph, K.: VIPOL, p. 504.

4. Danilenko L. I. (2001), Teoriya i praktyka innovatsiynoyi diyal'nosti v zahal'niy seredniy shkoli [Theory and practice of innovation activity in general secondary school], Management of education, №3, pp. 18-24.

5. Avtshenyuk N.M., Dyachenko L.M., Kotun K.V., Marusinets M.M., Ogienko O.I., Sulima O.V., Postrihach N.O. (2017), Zarubizhnyy dosvid profesiynoyi pidhotovky pedahohiv : analitychni materialy [Foreign experience of professional training of teachers: analytical materials], Kyiv: DKS "Center", pp. 83. 